\title{
INFLATION AND FINANCIAL SECTOR PERFORMANCE: THE CASE OF NIGERIA
}

\author{
R. Santos ALIMI 1
}

DOI: 10.2478/tjeb-2014-0003

\begin{abstract}
The paper examines the long run and short run relationships between inflation and the financial sector development in Nigeria over the period between 1970 and 2012. Three variables, namely; broad definition of money as ratio of GDP, quasi money as share of GDP and credit to private sector as share of GDP, were used to proxy financial sector development. Our findings suggest that inflation presented deleterious effects on financial development over the study period. The main implication of the results is that poor macroeconomic performance has deleterious effects to financial development - a variable that is important for affecting economic growth and income inequality. Moreover, we observed a negative effect of the measures of financial development on growth, suggesting that impact of inflation on the economic growth passes through financial sector. Therefore, low and stable prices, is a necessary first step to achieving a deeper and more active financial sector that will enhance growth as predicted by Schumpeter.
\end{abstract}

Keywords:

Financial Sector Development, Inflation.

JEL Classification: D44, E31, 055.

${ }^{1}$ Lecturer, Adekunle Ajasin University, Nigeria. 


\section{Introduction}

The relevance of understanding the macroeconomic determinants of financial development lies in the fact that a more active financial sector is of great importance for economic growth and income inequality, which are of high priority in macroeconomic objectives of any developing countrys, like Nigeria. Both theoretical and empirical evidences reveal that developed financial sector mobilizes savings efficiently and reallocates the resources to productive activities and subsequently stimulates economic activities in the country. For instance, while the studies of King and Levine (1993), Levine and Zervos (1998), Beck, et al. (2000), and Beck and Levine (2004) report that financial development has a positive impact on long-run growth, Li, et al. (1998), Dollar and Kraay (2002), Clark, et al. (2003), Odiambho (2004), Bonfiglioli (2005), Bittencourt (2007a) and Beck, et al. (2007) on the other hand established that financial development reduces income inequality.

However, high rate of inflation worsens the efficiency of financial sector through financial market frictions and slows down the economic performance. Therefore, high inflation rate has become not only a concern in the industrial and emerging market economies but to the general economy of nations, hence price stability becomes the focus of monetary authorities upon overwhelming empirical evidence that it is only in the midst of price stability that sustainable growth can be achieved. Inflationary conditions imply that general price level keeps increasing over time. Low and stable inflation rates allow the private sector to plan for the future, lead to a lower need for costly price adjustments, prevent tax distortion and thus create a stable business environment (Bencivenga and Smith, 1993). Thus, the policy makers are so obsessed about inflation because of its implication on the economy such as; it discourages long term planning, reduces savings and capital accumulation, reduces investment, brings about shift in the distribution of real income and consequent misallocation of resources and creates uncertainty and distortions in the information content of prices.

An overview of inflation trend shows that average inflation during the period 1960-1972 was relatively low, the historical average rate being 5.01 percent. The period 1973-1985 was one of greater inflationary pressures than the period 1960-1972, with an average inflation rate of 17.96 percent. As a result of the measures put in place, the rate of inflation was significantly brought down in the late 1970s. However, the upward trend resumed in 1981, when the inflation rate went up by 20.80 percent. The period 1986-1994 represented a time of greater inflationary pressures than the other preceding periods, as indicated by a historical average rate of 31.50 percent. When inflation experience is taken on a year-by-year basis, it is found that 1986 and 1987 recorded relatively low rates of 5.40 percent and 10.20 percent, respectively. In 1988-1999, the historical average rate was about 34 percent. The inflationary pressures during the Structural Adjustment Programme (SAP) era of 1986 - 1990 were largely attributed to wholesale depreciation of the naira on the foreign exchange market, which increased the naira prices of imported goods including raw materials and capital goods, as well as an

\section{DE GRUYTER OPEN}


Alimi, R. S. (2014).

unprecedented growth in money supply, during this period. Figure 1 further show that from year 2000 up to 2012, inflation rate on average is of 12.3 percent, in spite of the monetary authority policies targeted towards a single digit inflation rate.

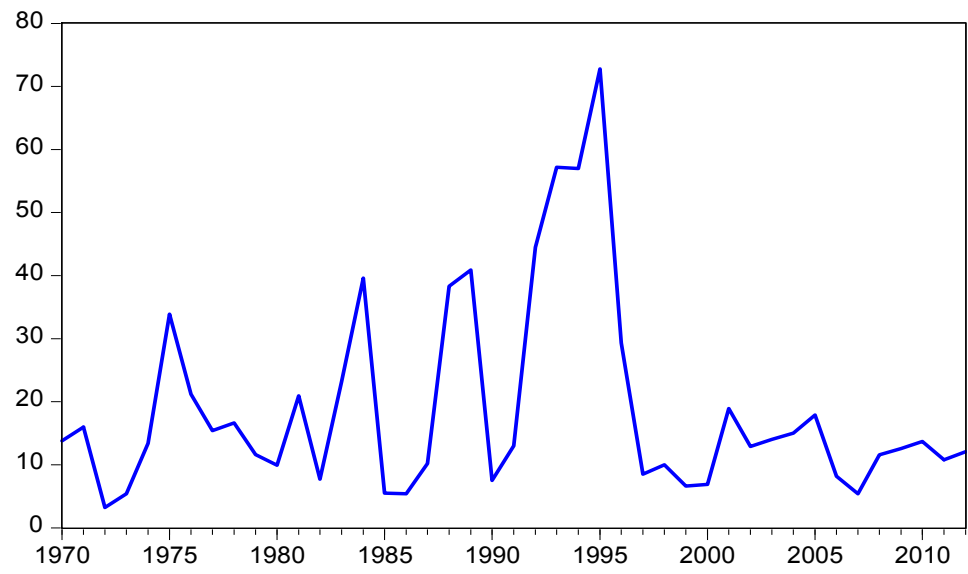

Figure 1 Nigeria: Inflation Rate 1970-2012

Empirical studies such as the works of Haslag and Koo (1999), Boyd et al. (2001), Zoli (2007), Dehesa, et al. (2007), Azariadis and Smith (1996) and Murombedzi (2008), have shown that high rate of inflation worsens the efficiency of financial sector through financial market frictions, subsequently reduce the level of investment and slows down the economic performance. In the study of Barnes, Boyd, and Smith (1998), they suggest that higher inflation does not tend to result in proportionately higher nominal interest rates but high inflation results in lower real rates of return. This increases the demand for loanable funds, but reduces their supply. Smith and van Egteren (2005) suggest another mechanism by which inflation can impact real output. In their model, inflation both lowers the real value of internal funds used by firms to make investment and distorts firms' incentives to accumulate internal funds. This causes firms to rely more heavily on external sources of funds, exacerbating informational frictions in financial markets. This adversely impacts the level and efficiency of investment, resulting in lower real output. Another potential linkage between inflation and levels of financial development is through reserve requirements. High rates of inflation can serve as a significant tax on banks, especially in those developing countries with high levels of reserve requirements (Boyd \& Champ, 2003).

Some studies however found a positive relationship between inflation and financial development, case in which higher permanent inflation leads to higher real economic activity or to super-neutrality, where higher inflation has no effect on real interest rates, or real activity. Studies among which hold this assertion is those of Mundell (1963) and Tobin (1965), English (1999), Bittencourt (2011).

\section{DE GRUYTER} OPEN
Timisoara Journal of Economics and Business | ISSN: 2286-0991 | www.tjeb.ro Year 2014 | Volume 7 | Issue 1 | Pages: 55-69 
Alimi, R. S. (2014).

of Economics and Business

Inflation and Financial Sector Performance: the Case of Nigeria

There is scare study in Nigeria on the link between inflation and financial development. Thus, the main objective of this study is to investigate the relationship between inflation and financial development by employing short run dynamics within ECM Framework. The study proceeds as follows. Section 2 presents details on data and models, followed by methodological framework in section 3 . Section 4 provides detailed analysis of the regression results and the paper ends in section 5 with some concluding remarks.

\section{Data and Model}

We specify a log-linear model for the study in order to estimate the responses of financial variables to inflation. The study uses macroeconomic series that consist of yearly observations between 1970 and 2012. We estimate the following three models for Nigeria.

Model A:

$\operatorname{lnFDM} 2_{t}=\delta+\gamma_{1} \ln F D M 2_{t-1}+\gamma_{2} I N F_{t}+\gamma_{3} \ln R G D P_{t}+\gamma_{4} \operatorname{lnGOVT_{t}}+\gamma_{5} \ln T O P N_{t}+\mu_{t}$

Model B:

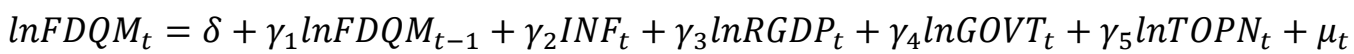

Model C:

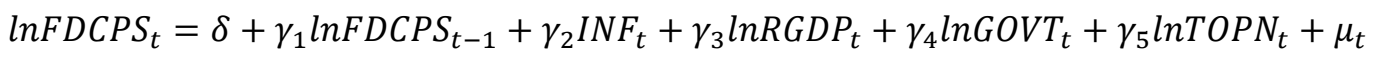

where

$\mu$ - the error term.

FDM2 - money in circulation in the economy plus current account and savings deposits and foreign currency deposit in the financial institutions as ratio of GDP.

$F D Q M$ - quasi money (time deposit, savings and foreign currency deposits in the financial institutions) as share of GDP.

FDCPS - as credit to private sector as share of GDP.

$R G D P$ - real gross domestic product used to capture the real output.

GOVT - total government spending.

$I N F$ - inflation rate.

TOPN - trade openness measured as the ratio of the sum of export and import to GDP.

DE GRUYTER OPEN
Timisoara Journal of Economics and Business | ISSN: 2286-0991 | www.tjeb.ro

Year 2014 | Volume 7 | Issue 1 | Pages: 55-69 
Alimi, R. S. (2014).

Inflation and Financial Sector Performance: the Case of Nigeria

We included three macroeconomic control variables: real gross domestic product $(R G D P)$, trade openness (TOPN) and government expenditure (GOVT) to avoid simultaneous bias (Gujarati, 2006) in our regressions. The incorporation of control variables also helps to make our analysis multivariate as against bivariate. This is important because bivariate causality leads to erroneous causal inferences (Lutkepohl, 1982; Caporale and Pittis, 1995). We use the natural log of the three control variable because natural logarithm of a series effectively linearizes the exponential trend (if any) in the time series data since the log function is the inverse of an exponential function (Asteriou and Price, 2007). Moreover, opting for log of the variables may prevent cumbersomeness in the modelling and inference and it allows the regression coefficients to be interpreted as elasticity (Rahaman and Salahuddin, 2010). Annual data of all variables have been collected from World Bank, and International Financial Statistics (IFS) and CBN Statistical Bulletin. Table 1 provides the descriptive statistics of the variables of interest in this study.

Table 1

Descriptive Statistics

\begin{tabular}{cccccccc}
\hline & \multicolumn{3}{c}{ Financial Variables } & \multicolumn{4}{c}{ Control Variables } \\
& InFDM2 & InFDQM & InFDCPS & INFL & InRGDP & LnGOVT & InTOPN \\
\hline Observations & 43 & 43 & 43 & 43 & 43 & 43 & 43 \\
Mean & 3.0916 & -1.2041 & 2.6400 & 19.0330 & 12.0483 & 4.4744 & -6.570907 \\
Median & 3.0812 & -1.8484 & 2.5645 & 13.4000 & 12.7027 & 4.1984 & -7.211589 \\
Maximum & 3.6364 & 2.1554 & 3.6030 & 72.8000 & 13.6977 & 8.4578 & -3.528566 \\
Minimum & 2.2318 & -3.6936 & 1.5637 & 3.2000 & 8.3473 & -0.1009 & -9.758316 \\
Std. Dev. & 0.3288 & 1.7728 & 0.4611 & 15.8787 & 1.5681 & 2.6595 & 1.967769 \\
Skewness & -0.3044 & 0.6078 & 0.0654 & 1.7118 & -1.2249 & -0.0210 & 0.061977 \\
Kurtosis & 2.5056 & 2.0500 & 2.7133 & 5.3416 & 3.17974 & 1.6859 & 1.715915 \\
Jarque-Bera & 1.1021 & 4.2649 & 0.1779 & 30.8242 & 10.8106 & 3.0970 & 2.981762 \\
Probability & 0.5763 & 0.1185 & 0.9148 & 0.0000 & 0.0044 & 0.2125 & 0.225174 \\
\hline
\end{tabular}

Source: Own preparation.

Table 2 predicts that inflation is inversely but weakly linked with the financial sector development variables, Trade Openness (TOPN) and total government expenditures (GOVT). Financial development variable is associated positively and strongly (but weakly when lnFDM2 is used as a measure of financial development) with RGDP and GOVT. 
Alimi, R. S. (2014).

Inflation and Financial Sector Performance: the Case of Nigeria

Table 2

Correlation Matrix

\begin{tabular}{cccccccc}
\hline & \multicolumn{3}{c}{ Financial Variables } & \multicolumn{3}{c}{ Control Variables } \\
& InFDM2 & InFDQM & InFDCPS & INFL & InRGDP & LnGOVT & InTOPN \\
\hline Financial Variable & 1.0000 & 1.0000 & 1.0000 & & & & \\
INFL & -0.0631 & -0.1796 & -0.0778 & 1.0000 & & & \\
LnRGDP & 0.5584 & 0.5764 & 0.6764 & 0.1275 & 1.0000 & & \\
LnGOVT & 0.3327 & 0.9035 & 0.5237 & -0.0200 & 0.8509 & 1.0000 & \\
LnTOPN & -0.0217 & 0.9590 & 0.1996 & -0.1246 & 0.4871 & 0.8662 & 1.0000 \\
\hline
\end{tabular}

Source: Own preparation.

\section{Methodological Framework}

In this study, our empirical investigation consists of three main steps. First, we examine the stationarity of our variables. A non-stationary time series has a different mean at different points in time, and its variance increases with the sample size (Harris and Sollis (2003). A characteristic of non- stationary time series is extremely crucial, in the sense that the linear combinations of these time series make spurious regression. In the case of spurious regression, t-values of the coefficients are highly significant, coefficient of determination (R2) is very close to one and the Durbin Watson (DW) statistic value is very low, which often lead investigators to commit a high frequency of Type 1 errors (Granger and Newbold, 1974). In that case, the results of the estimation of the coefficient became biased. Therefore it is necessary to detect the existence of stationarity or non-stationarity in the series to avoid spurious regression. For this, the unit root tests are conducted using DF-GLS, and Ng-Perron. If a unit root is detected for more than one variable, we further conduct the test for cointegration, to determine whether we should use Error Correction Mechanism (ECM) or not.

Second, cointegration tests are conducted to see if there is a long-run or equilibrium relationship between the variables. Two popular cointegration tests, namely, the Engel-Granger (EG) test and the Johansen test are used. The EG test is contained in Engel and Granger (1987), while the Johansen test is found in Johansen (1988) and Johansen and Juselius (1990). The EG test involves testing for stationarity of the residuals. If the residuals are stationary at level, it implies that the variables under consideration are cointegrated. The EG approach could exhibit some degree of bias arising from the stationarity test of the residuals from the chosen equation. The EG test assumes one cointegrating vector in systems with more than two variables and it assumes arbitrary normalization of the cointegrating vector. Besides, the EG test is not very powerful and robust when compared with the Johansen cointegration test. Thus, it is necessary to complement the EG test with the Johansen test.

We shall employ ordinary least square (OLS) estimation technique for the case where there is evidence of long run relationship among our variables of interest. With regard to the estimation of

\section{DE GRUYTER OPEN}

Timisoara Journal of Economics and Business | ISSN: 2286-0991 | www.tjeb.ro Year 2014 | Volume 7 | Issue 1 | Pages: 55-69 
Alimi, R. S. (2014).

cointegrating regression models, it is well known that the ordinary least squares (OLS) estimator contains the second-order bias, comprising the endogeneity bias and the non-centrality bias, when the I(1) regressors are endogenous and/or the regression errors are serially correlated. Thus, we will apply canonical cointegrating regression (CCR), one of the several efficient methods for the estimation of the cointegrating regressions found in literature, as an alternative estimation method. Park (1992) proposed the canonical cointegrating regression (CCR) method, which is based on a nonparametric correction for the OLS estimator.

Granger (1988) demonstrates that causal relations among variables can be examined within the framework of ECM, with cointegrated variables. While the short run dynamics are captured by the individual coefficients of the lagged terms, the error correction term (ECT) contains the information of long run causality. Significance of lagged explanatory variable depicts short run causality while a negative and statistical significant ECT is assumed to signify long run causality (Bannerjee and Newman, 1998). We specify the error correction term as follows:

$$
\begin{aligned}
& \operatorname{lnFDM} 2_{t}=\delta+\gamma_{1} \operatorname{lnFDM} 2_{t-1}+\gamma_{2} I N F_{t}+\gamma_{3} \ln R G D P_{t}+\gamma_{4} \ln G O V T_{t}+\gamma_{5} \operatorname{lnTOPN}_{t}+\mu_{t} \\
& \mu_{t}=\ln F D M 2_{t}+\delta+\gamma_{1} \ln F D M 2_{t-1}+\gamma_{2} I N F_{t}+\gamma_{3} \ln R G D P_{t}+\gamma_{4} \operatorname{lnGOVT_{t}}+\gamma_{5} \operatorname{lnTOPN}_{t}
\end{aligned}
$$

where $\mu_{t}$ is the residual term and $\gamma$ is a cointegrating coefficient. From equation (5), we can formulate a simple ECM as:

$$
\begin{aligned}
\Delta \operatorname{lnFDM} 2_{t}= & \\
& \varphi_{1}+\varphi_{2} \Delta \operatorname{lnFDM} 2_{t-1}+\varphi_{3} \Delta I N F_{t}+\varphi_{4} \Delta \ln R G D P_{t}+\varphi_{5} \Delta \ln G O V T_{t}+ \\
& +\varphi_{6} \Delta \operatorname{lnTOP} N_{t}+\Omega \mu_{t-1}+v_{t}
\end{aligned}
$$

Specifically from the ECM expressed in equation (6), $\varphi$ captures any immediate, short term or contemporaneous effect that the explanatory variables have on the financial variable. The coefficient $\gamma_{i}$ reflects the long-run equilibrium effect of INF, RGDP, GOVT and TOPN on FDM2 and the absolute value of $\Omega$ decides how quickly the equilibrium is restored. We can therefore say that $\gamma_{i}$ and $\Omega$ are the short-run parameters while $\varphi_{i}$ is the long-run parameter (similarly construct ECM from equations 2 and 3 ).

\section{Empirical Results and Discussion}

In order to examine the integrating level of variables, standard tests like DF-GLS, and Ng-Perron are employed. Mostly in the literature to find out the order of integration ADF (Dicky \& Fuller, 1979) and PP (Philip \& Perron, 1988) tests have been used extensively. Due to their poor size and power properties, both tests are not reliable for small sample data set (Dejong et al, 1992).

\section{DE GRUYTER OPEN}

Timisoara Journal of Economics and Business | ISSN: 2286-0991 | www.tjeb.ro Year 2014 | Volume 7 | Issue 1 | Pages: 55-69 
Alimi, R. S. (2014).

Inflation and Financial Sector Performance: the Case of Nigeria

These tests seem to over-reject the null hypotheses when it is true, and accept it when it is false. While newly proposed tests, such as Dicky-Fuller generalized least square (DF-GLS) detrending test developed by Elliot et al. (1996) and Ng-Perron test following Ng-Perron (2001) seem to solve this arising problem.

Table 3

DF-GLS Unit Root Test

\begin{tabular}{ccc}
\hline Variables in: & Levels & First differences \\
\hline InRGDP & -0.234997 & $-6.098889 \mathrm{a}$ \\
InGOVT & 1.269989 & $-7.549572 \mathrm{a}$ \\
INFL & $-3.247812 \mathrm{a}$ & - \\
InTOPN & -0.18519 & $-6.260638 \mathrm{a}$ \\
InFDM2 & -1.518233 & $-6.531638 \mathrm{a}$ \\
InFDQM & 0.745064 & $-6.393032 \mathrm{a}$ \\
InFDCPS & -0.875320 & $-5.503878 \mathrm{a}$ \\
\hline
\end{tabular}

Source: Own preparation.

Table 4

Ng-Perron Unit Root Test

\begin{tabular}{ccccc}
\hline Level & MZa & MZt & MSB & MPT \\
\hline InRGDP & 0.37870 & 0.31650 & 0.83575 & 44.6801 \\
InGOVT & 1.45987 & 2.00951 & 1.376650 & 137.505 \\
INFL & $-13.6711 \mathrm{~b}$ & -2.61089 & 0.19098 & 1.80598 \\
InTOPN & 0.09432 & 0.05735 & 0.60805 & 25.4304 \\
InFDM2 & -4.77005 & -1.35296 & 0.28364 & 5.53171 \\
InFDQM & 1.27314 & 0.88698 & 0.69669 & 39.0709 \\
FDCPS & -2.15737 & -0.68962 & 8.82966 & \\
\hline \hline First Difference & MZa & MZt & MSB & MPT \\
\hline InRGDP & $-20.4732 a$ & -3.19861 & 0.15623 & 1.19973 \\
InGOVT & $-19.8249 \mathrm{a}$ & -3.13378 & 0.15807 & 1.28770 \\
INFL & - & - & - & - \\
InTOPN & $-20.4746 \mathrm{a}$ & -3.19095 & 0.15585 & 1.22696 \\
InFDM2 & $-20.4658 \mathrm{a}$ & -3.19493 & 0.15611 & 1.21108 \\
InFDQM & $-20.4777 \mathrm{a}$ & -3.19948 & 0.15624 & 1.19763 \\
InFDCPS & $-20.0654 a$ & -3.16138 & 0.15755 & 1.24246 \\
\hline
\end{tabular}

Source: Own preparation. Note: *Ng-Perron (2001, Table 1) \&*Mackinnon (1996); a (1\%), b (5\%) \& c (10\%).

The unit root results reported in Tables 3 and 4 show that all the series, except for inflation, are non-stationary at level, but become stationary after taking their first difference i.e. I(1). Thus we apply the Engel - Granger cointegration to test long run relationship between the variables. Following the modeling approach described earlier, we determine the appropriate lag length and conducted the cointegration test.

DE GRUYTER OPEN
Timisoara Journal of Economics and Business | ISSN: 2286-0991 | www.tjeb.ro Year 2014 | Volume 7 | Issue 1 | Pages: 55-69 
Alimi, R. S. (2014).

Inflation and Financial Sector Performance: the Case of Nigeria

Table 5

Lag Length Selection

\begin{tabular}{cccccc}
\hline Lag & LR & FPE & AIC & SC & HQ \\
\hline $\mathbf{0}$ & NA & $9.01 \mathrm{e}-06$ & 5.409483 & 5.665415 & 5.501309 \\
$\mathbf{1}$ & $318.4992^{*}$ & $2.78 \mathrm{e}-09^{*}$ & $-2.697463^{*}$ & $-0905935^{*}$ & $-2.054678^{*}$ \\
$\mathbf{2}$ & 32.43978 & $5.79 \mathrm{e}-09$ & -2.098993 & 1.228130 & -0.905250 \\
$\mathbf{3}$ & 30.20399 & $1.19 \mathrm{e}-08$ & -1.763039 & 3.099680 & -0.018337 \\
$\mathbf{4}$ & 26.81656 & $2.69 \mathrm{e}-08$ & -1.832353 & 4.565961 & 0.463307 \\
\hline
\end{tabular}

Source: Own preparation. Note:*indicates lag order selected by the criterion ;LR: sequential modified LR test statistics (each test at 5\% level); FPE: Final Prediction Error; AIC: Akaike Information Criterion; SC: Schwarz Information Criterion; HQ: Hannan-Quinn Information Criterion.

Table 5 reports the optimal lag length of one out of a maximum of 4 lag lengths as selected by the five criterions. The EG test presented in Table 4 show that the series in models $B$ and $C$ are integrated of order one at the $1 \%$ significance level and the residuals of model $A$ is stationary at level under Augmented Dickey-Fuller (ADF) and Philip-Perron (PP) unit root tests. Therefore, the Engel - Granger cointegration test indicates that the variables are cointegrated only for models A. Whereas KPSS unit root test does not rejected the null hypothesis of stationarity at $10 \%$ for the three models, thereby suggesting the three models are cointegrated.

Table 6

Stationarity Test of the Residuals

\begin{tabular}{cccccc}
\hline Model & Variable & ADF & PP & KPSS & $\begin{array}{c}\text { Order of } \\
\text { Integration }\end{array}$ \\
\hline Model A & Residual & $\begin{array}{c}-2.6205^{*} \\
(0.0969)\end{array}$ & $\begin{array}{c}-2.6160^{*} \\
(0.0978)\end{array}$ & 0.120771 & $\mathrm{I}(0)$ \\
Model B & Residual & $\begin{array}{c}-0.6440 * * \\
(0.000)\end{array}$ & $\begin{array}{c}-0.6645 * * \\
(0.000)\end{array}$ & 0.130540 & $\mathrm{I}(1)$ \\
Model C & Residual & $\begin{array}{c}-5.050)^{* * *} \\
(0.0002)\end{array}$ & $\begin{array}{c}-6.0542 * * * \\
(0.0000)\end{array}$ & 0.114704 & $\mathrm{I}(1)$ \\
\hline
\end{tabular}

Source: Own preparation. Note: P-values in bracket (); The null hypothesis is that the series is stationary. The critical values of KPSS for $1 \%, 5 \%$, and $10 \%$ levels are, respectively: $0.7390,0.4630$ and 0.3470

To complement the EG test, the Johansen test is conducted and reported in Table 7. Empirical findings show that both the maximum eigenvalue and the trace tests reject the null hypothesis of no cointegration at both 5 percent significance level for model B while the two tests do not reject the null hypothesis of no cointegration at both 5 percent significance level for model $\mathrm{C}$. Whereas, trace test reject the null hypothesis of no cointegration at both 5 percent significance level for model A and maximum eigenvalue do not reject the null hypothesis of no cointegration at the same level of significance. The results in Table 5 are based on the assumptions of linear deterministic trend and lag interval in first difference of 1 to 1 . Overall, the cointegration tests tend to suggest that there is non-existence of a sustainable long-run relationship between financial deepening proxied by ratio of credit to private sector to gross domestic product and

\section{DE GRUYTER OPEN}

Timisoara Journal of Economics and Business | ISSN: 2286-0991 | www.tjeb.ro Year 2014 | Volume 7 | Issue 1 | Pages: 55-69 
Alimi, R. S. (2014).

Inflation and Financial Sector Performance: the Case of Nigeria

other selected variables (model C). However, there is evidence of long run relationship for models A under both Engel-Granger and Johansen-Juselius i.e a cointegration rank of one in trace test at $5 \%$ significance level. Cointegration tests for model $B$ are inconclusive from the two cointegration tests.

Table 7

Johansen Cointegration Test

\begin{tabular}{|c|c|c|c|c|c|c|c|c|}
\hline & \multirow[b]{2}{*}{$\begin{array}{c}\text { Null } \\
\text { Hypothesis }\end{array}$} & \multirow[b]{2}{*}{$\begin{array}{c}0.05 \\
\text { Critical } \\
\text { Values }\end{array}$} & \multicolumn{2}{|c|}{ Model A } & \multicolumn{2}{|c|}{ Model B } & \multicolumn{2}{|c|}{ Model C } \\
\hline & & & $\begin{array}{c}\text { Test } \\
\text { Statistics }\end{array}$ & $\begin{array}{l}\text { Prob. } \\
\text { Value }\end{array}$ & $\begin{array}{c}\text { Test } \\
\text { Statistics }\end{array}$ & $\begin{array}{l}\text { Prob. } \\
\text { Value }\end{array}$ & $\begin{array}{c}\text { Test } \\
\text { Statistics }\end{array}$ & $\begin{array}{l}\text { Prob. } \\
\text { Value }\end{array}$ \\
\hline Lags & & & 1 & & 1 & & 1 & \\
\hline Trace & $r=0$ & 69.8188 & 72.7494* & 0.0286 & $71.1275^{*}$ & 0.0392 & 67.9398 & 0.0699 \\
\hline Statistics & $r=1$ & 47.8561 & 41.4103 & 0.1759 & 35.9231 & 0.4002 & 37.2652 & 0.3351 \\
\hline Max-Eigen & $r=0$ & 33.8768 & 31.3391 & 0.0975 & 35.2044 * & 0.0345 & 30.6745 & 0.1151 \\
\hline Statistics & $r \leq 1$ & 27.5843 & 16.9265 & 0.5863 & 19.8237 & 0.3534 & 15.7849 & 0.6839 \\
\hline Trace & No of Vectors & & 1 & & 1 & & & 0 \\
\hline Max-Eigen & No of Vectors & & 0 & & 1 & & & 0 \\
\hline
\end{tabular}

Source: Own preparation. Note: * denotes rejection of the null hypothesis at 0.05 level.

Based on the existence of cointegration relationship for model A (possibly models B \& C at $10 \%$ significance level), we therefore estimate the long-run relationships using the ordinary least squares (OLS) model.

Table $8 a$ and $8 b$ give preliminary results of equations $1-3$, using OLS with the HAC or NeweyWest standard error that takes into account the autocorrelation and Canonical Cointegrating Regression. We found that the coefficients estimates of the variables and their signs are similar in both estimation techniques, however, only trade openness variable in model $A$ and inflation variable in model $B$ are statistically significant at ten percent level.

\section{Table 8a}

OLS Long Run Coefficient Estimates

\begin{tabular}{cccc}
\hline Regressors & Model A & Model B & Model C \\
\hline Constant & $1.447051 * * *$ & $3.325269 * * *$ & 0.376345 \\
INFL & $-0.003201 * *$ & $-0.007796 * *$ & $-0.004603 * *$ \\
LnRGDP & $-0.237485^{*}$ & $-0.580191 * *$ & -0.199146 \\
LnTOPN & $-0.408030 * * *$ & 0.146637 & $-0.413170 * * *$ \\
LnGOVT & $0.421420 * * *$ & $0.798481 * * *$ & $0.454971 * *$ \\
\hline
\end{tabular}

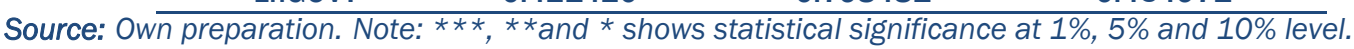

Following from Table 8a, the result shows that the three measures of financial development fared against inflation and that inflation presents a clear negative effect on all measures of financial development. Also, the effects caused by other variables on financial development follow this pattern; negative effects of real gross domestic product and trade openness on financial

\section{DE GRUYTER OPEN}

Timisoara Journal of Economics and Business | ISSN: 2286-0991 | www.tjeb.ro Year 2014 | Volume 7 | Issue 1 | Pages: 55-69 
Alimi, R. S. (2014).

development and positive effects caused by government spending. The study shows that inflation has a minimal, but damaging effect on financial development. For instance, a unit increase in inflation rate will bring about a $0.32 \%$ fall in financial development in Model $\mathrm{A}, 0.78 \%$ in Model $\mathrm{B}$, and $0.46 \%$ in Model C. This shows that inflationary environment deteriorates financial development plausibly through lowering of money supply and thus restricting financial resources for investment projects. Moreover, inflation severely curtails the provision of payment-deferring instruments and it is linked with high opportunity cost of holding money which reduces the efficiency of financial institutions, hence development of financial sector (Wahid et al, 2011). Similar to the findings of Shen and Lee (2006), we observed a negative effect of the measures of financial development on growth. This implies that monies mobilized by the banking financial institution is not channel to the real sector, striving cases of capital flight might be a plausible explanation for our results.

\section{Table 8b}

Canonical Cointegrating Regression (CCR) Estimates

\begin{tabular}{cccc}
\hline Regressors & Model A & Model B & Model C \\
\hline Constant & $1.322434^{*}$ & $3.085830^{* *}$ & 0.109222 \\
INFL & -0.004848 & $-0.012685^{*}$ & -0.006749 \\
LnRGDP & -0.222680 & -0.533610 & -0.113983 \\
LnTOPN & $-0.408609 *$ & 0.161332 & -0.357900 \\
LnGOVT & 0.424586 & 0.779830 & 0.386359 \\
\hline
\end{tabular}

Source: Own preparation. Note: ***, **and * shows statistical significance at 1\%, 5\% and 10\% level.

The coefficients of ECM term for the three models are reported in Table 9. They are negative and statistically significant, thus confirming our finding under both Engel-Granger and JohansenJuselius cointegration tests that there is evidence of long run causality between respective explanatory variable and its regressors. In the short-run, when broad money definition and credit to private sectors, as share of GDP, were used to capture financial deepening in Nigeria, models $A$ and $C$ suggest that only real output and trade openness cause the changes in financial deepening. Similarly, short run dynamics of model B reveals that real output and government spending has significant effect on financial development. The short run dynamics suggests that the effect of inflation on financial development is minimal and statistically not significant. The estimate of lagged ECM term also identifies the speed of adjustment from short run towards long run equilibrium path. Our empirical evidence showed that the estimated values of the coefficients of ECM1-t are $-0.2939,-0.1095$ and -0.2430 for models A, B and C respectively and it is statically significant at 10 percent significance level. This shows that any changes in short run towards long run is corrected by about 30 percent per year in development of financial sector based on model A specification.

\section{DE GRUYTER OPEN}

Timisoara Journal of Economics and Business | ISSN: 2286-0991 | www.tjeb.ro Year 2014 | Volume 7 | Issue 1 | Pages: 55-69 
Alimi, R. S. (2014).

Inflation and Financial Sector Performance: the Case of Nigeria

Table 9

ECM Short Run Coefficient Estimates

\begin{tabular}{cccc}
\hline Regressors & $\Delta($ InFDM2) & $\Delta($ InFDQM) & $\Delta($ InFDCPS $)$ \\
\hline Constant & $0.081314^{*}$ & $0.146484 * *$ & 0.076267 \\
& $(0.0943)$ & $(0.0075)$ & $(0.2618)$ \\
D(InRGDP) & $-0.372962 * *$ & $-0.963973^{*} *$ & $-0.408142 * * *$ \\
& $(0.0003)$ & $(0.000)$ & $(0.0046)$ \\
D(InRGDP(-1)) & -0.038376 & 0.256705 & -0.013026 \\
& $(0.7351)$ & $(0.2420)$ & $(0.9331)$ \\
D(InGOVT) & 0.135199 & $0.176666^{*}$ & $0.259332^{*}$ \\
& $(0.1677)$ & $(0.0542)$ & $(0.0707)$ \\
D(InGOVT(-1)) & 0.048249 & -0.043241 & 0.005302 \\
& $(0.6710)$ & $(0.6691)$ & $(0.9709)$ \\
D(INFL) & 0.001785 & $9.29 \mathrm{e}-05$ & 0.000697 \\
& $(0.2533)$ & $(0.9535)$ & $(0.7461)$ \\
D(INFL(-1)) & -0.001147 & 0.000256 & -0.001337 \\
& $(0.5134)$ & $(0.8657)$ & $(0.5619)$ \\
D(InTOPN) & $-0.418637 * *$ & -0.003466 & $-0.469398 * *$ \\
& $(0.0000)$ & $(0.9590)$ & $(0.0001)$ \\
D(InTOPN(-1)) & -0.067040 & 0.022283 & -0.030312 \\
& $(0.4821)$ & $(0.7438)$ & $(0.8123)$ \\
D(Financial Variable(-1)) & -0.060276 & 0.233775 & 0.092086 \\
& $(0.7129)$ & $(0.2317)$ & $(0.6398)$ \\
Ecm(-1) & $-0.293974 * *$ & $-0.109520 *$ & $-0.243029 *$ \\
& $(0.0378)$ & $(0.0898)$ & $(0.0588)$ \\
\hline
\end{tabular}

Source: Own preparation. Note: $p$-value in (); **, **and * shows statistical significance at 1\%, 5\% and $10 \%$ level.

\section{Conclusions and Policy Implications}

The paper examines the relationship between inflation and financial sector development in Nigeria, over the period between 1970 and 2012. Three variables, namely: broad definition of money as ratio of GDP, quasi money as share of GDP and credit to private sector as share of GDP, were used to proxy financial sector development. Our findings suggest that inflation presented deleterious effects on financial development over the study period. The main implication of the results is that poor macroeconomic performance has deleterious effects to financial development - a variable that is important for affecting economic growth and income inequality. Moreover, we observed a negative effect of the measures of financial development on growth, suggesting that impact of inflation on the economic growth passes through financial sector. This result can be compared to those of Boyd and Champ (2003) who found that inflation hurts economic growth through declining financial development, especially by damaging the operation of financial markets. Furthermore, a plausible explanation for the observed negative effect on growth might be due to the fact that monies mobilized by the banking financial institution are not channelled to the real productive sector because of striving cases of capital flight. Therefore, low and stable prices, is a necessary first step to achieving a deeper and more active financial sector that will enhance growth as predicted by Schumpeter .

DE GRUYTER OPEN
Timisoara Journal of Economics and Business | ISSN: 2286-0991 | www.tjeb.ro Year 2014 | Volume 7 | Issue 1 | Pages: 55-69 


\section{References}

Asteriou, D. \& Price, S. (2007). Applied Econometrics, A Modern Approach. Basingstoke: Palgrave Macmillan.

Azariadis, C. \& Smith, B. D. (1996). Private Information, Money, and Growth: Indeterminacy, Fluctuations, and the Mundell-Tobin Effect. Journal of Economic Growth, 1, 309332.

Bannerjee, A. V. \& Newman, A. F. (1998). Occupational Choice and the Process of Development. Journal of Political Economy, 101, 274-298.

Barnes, M., Boyd, J. H. \& Smith, B. D. (1999). Inflation and Asset Returns. European Economic Review, 43, 737-754

Beck, T. Demirguc-Kunt, A, \& Levine, R. (2007). Finance, Inequality, and the Poor. Journal of Economic Growth, 12(1), 27-49.

Beck, T., Demirguc-Kunt, A., Levine, R. \& Maksimovic, V. (2000). Financial Structure and Economic Development - Firm, Industry, and Country Evidence, Policy Research Working Paper Series 2423, The World Bank.

Beck, T. \& Levine, R. (2004). Stock Markets, Banks and Growth: Panel Evidence. Journal of Banking and Finance, 28, 423-442.

Bencivenga, V. R. \& Smith, B. D. (1993). Some Consequences of Credit Rationing in an Endogenous Growth Model. Journal of Economic Dynamics and Control, 17, 97-122.

Bittencourt, M. (2007). Financial Development and Inequality: Brazil 1985-99. Ibero-America Institute for Economic Research (IAI) Discussion Papers 164.

Bittencourt, M. (2011). Inflation and Financial Development: Evidence from Brazil, Economic Modeling, 28, 91-99.

Bonfiglioli, A. (2005). Equities and Inequality. IIES Seminar Paper 737.

Boyd J., Levine, R. \& Smith, B. (2001). The Impact of Inflation on Financial Market Performance. Journal of Monetary Economics, 47, 221-248.

Boyd, J., Champ, B. (2003). Inflation and Financial Market Performance: What Have We Learned in the Last Ten Years. Federal Reserve Bank of Cleveland 03-17.

Clarke, G. \& Xu, L.C. \& Zou, H. (2003). Finance and Income Inequality: Test of Alternative Theories. World Bank Policy Research Working Paper 2984.

Dehesa, M. \& Druck, P. \& Plekhnaov, A. (2007). Relative Price Stability, Creditor Rights, and Financial Deepening. IMF Working Paper 07/139.

DeJong, D. N., Nankervis, J. C., Savin, N.E \& Whiteman, C. H. (1992). Integration versus Trend Stationarity in Time Series. Econometrica, 60, 423-433.

Dickey, D. \& Fuller, W. (1979). Distribution Of The Estimators For Autoregressive Time Series With A Unit Root. Journal of the American Statistical Association, 74:427-731.

Dollar, D. \& Kraay, A. (2002). Growth is Good for the Poor. Journal of Economic Growth, 7: 195-225.

Elliot, G., Rothenberg, T. J., \& Stock, J. H. (1996). Efficient Tests for an Autoregressive Unit Root. Econometrica, 64, 813-36.

Engle, R. F. \& Granger, C. W. J. (1987). Cointegration and Error Correction Representation: Estimation and Testing. Econometrica, 55, 251-276.

DE GRUYTER OPEN
Timisoara Journal of Economics and Business | ISSN: 2286-0991 | www.tjeb.ro Year 2014 | Volume 7 | Issue 1 | Pages: 55-69 
Alimi, R. S. (2014).

Inflation and Financial Sector Performance: the Case of Nigeria

English, W. B. (1999). Inflation and Financial Sector Size. Journal of Monetary Economics, 44, $379-400$.

Granger, C. W. J. \& Newbold, P. (1974). Spurious Regression in Econometrics. Journal of Econometrics, 2, 111-120.

Granger, C.W.J. (1988). Causality, Cointegration and Control. Journal of Economic Dynamics and Control, 12, 551-559.

Gujarati, D.N (2006). Essential of Econometrics, $3^{\text {rd }}$ Edition, McGraw Hill, Boston.

Harris R. \& Sollis R. (2003). Applied Time Series Modelling and Forecasting. Wiley, Chichester.

Haslag, J. H. \& Koo, J. (1999). Financial Repression, Financial Development and Economic Growth. Federal Reserve Bank of Dallas Working Paper 99-02.

Johansen, S. (1988). The Mathematical Structure of Error Correction Models. Contemporary Mathematics, 80, 359-386

Johansen, S. \& Juselius, K. (1990). Maximum Likelihood Estimation and Inference on Cointegration with Application to the Demand for Money. Oxford Bulletin of Economics and Statistics, 52, 169-210.

King, R. G. \& Levine, R. (1993). Finance, Entrepreneurship and Growth: Theory and Evidence. Journal of Monetary Economics, 32, 513-542.

Levine, R. \& Zervos, S. (1998). Stock Markets, Banks, and Economic Growth. American Economic Review, 88, 537-558.

Li, H., Squire, L. \& Zou, H. (1998). Explaining International and Intertemporal Variations in Income Inequality. The Economic Journal, 108, 1-18.

Lütkepohl, H. 1982. Non-causality Due to Omitted Variables. Journal of Econometrics, 19, 367-378.

Mundell, R. (1963). Inflation and Real Interest. Journal of Political Economics, 71, 280-283.

Murombedzi, (2008), Inflation and Banking Development in Zimbabwe: The Financial Sector Perspective, Available at SSRN: http://ssrn.com/abstract=1273004.

Ng, S. \& Perron, P. (2001). Lag Length Selection and the Construction of Unit Root Tests with Good Size and Power. Econometrica, 69, 1519-1554.

Odeniran, S. O. \& Udeaja, E. A (2012). Financial Sector Development and Economic Growth: Empirical Evidence from Nigeria. CBN Economic and Financial Review Volume 48(3) September.

Odhiambo, N.M. (2004). Is Financial Development Still a Spur to Economic Growth? A Causal Evidence from South Africa. Savings and Development, 28, 47-62

Park, J.Y. (1992). Canonical Cointegrating Regressions. Econometrica, 60: 119-143.

Phillips P.C.B. \& Perron P. (1988). Testing for a Unit Root in a Time Series Regression. Biometrika, 75, 335-346

Rahman, M. M. \& Salahuddin, M. (2010). The Determinants of Economics Growth in Pakistan: Does Stock Market Development Play a Major Role? Economic Issues, 15(2), 69-86.

Schumpeter J.A. (1911). The Theory of Economic Development. Harvard University Press, Cambridge, MA.

Shen, C. \& Lee, C. (2006). Same Financial Development Yet Different Economic GrowthWhy? Journal of Money, Credit and Banking, 38(7), 1907-1944.

\section{OPEN}


Alimi, R. S. (2014).

Inflation and Financial Sector Performance: the Case of Nigeria

Smith, R. T. \& Van Egteren, H. (2005). Inflation, Investment, and Economic Performance: The Role of Internal Financing. European Economic Review, 49, 1283-1303.

Tobin, J. (1965). Money and Economic Growth. Econometrica, 33, 671-684.

Wahid, Abu N. M. and Shahbaz, M \& Azeem, P. (2011). Inflation and Financial Sector Correlation: The Case Of Bangladesh. International Journal of Economics and Financial Issues, 1(4),145-152.

Zoli, E. (2007). Financial Development in Emerging Europe: The Un-Finished Agenda. IMF Working Paper. 